\title{
Bibliographie sommaire de travaux critiques sur le thème « traduction et francophonie » en langues anglaise et française
}

\author{
Chiratidzo Mungoshi
}

Université de l'Alberta

- Almeida, Irène Assiba d', and Janis A. Mayes. A Rain of Words: A Bilingual Anthology of Women's Poetry in Francophone Africa. Charlottesville, VA: U of Virginia P, 2009.

- Almeida, Lilian Pestre de. "Ariettes retrouvées, contes recréés: Quelques aspects de la création chez Césaire dans ses rapports avec l'oralité." Etudes Creoles 8.1-2 (1985): 103-126.

- Almeida, Lilian Pestre de. "Traduire Césaire: Dialogue de cultures métissées." Oeuvres \& Critiques: Revue Internationale d'Etude de la Réception Critique d'Etude des CEuvres Littéraires de Langue 19.2 (1994): 125-140.

- Anderson, Debra. "Teaching Francophone Literature in Translation: Maryse Condé's I, Tituba, Black Witch of Salem." South Carolina Modern Language Review 1.1 (2002): 57-71.

- Antia, Bassey. (1999). "La traduction en anglais de la littérature francophone : perception du phénomène au Nigéria" [Translation into English of Literature in French from a Nigerian Perspective]. Meta 44.3(1999): 517-520.

- $\quad$ Ariole, Victor C. "Degré zéro syntaxique et la traduction." Babel: Revue Internationale de la Traduction/International Journal of Translation 53.4 (2007): 372-384.

- Ariole, Victor C. "Postcolonial Approach to Translation: Ideal Language as an Empty Set in Specific Target Audience Set." Babel: Revue Internationale de la Traduction/International Journal of Translation 47.3 (2001): 248-57.

- Ariole, Victor C. "La Recherche de scientificité en traduction." Babel: Revue Internationale de la Traduction/International Journal of Translation 42.2 (1996): 65-73.

- Arowolo, E. O. "Problems of Translation in African Writings." Présence Africaine : Revue Culturelle du Monde Noir/Cultural Review of the Negro World 123 (1982): 188-94.

- Asaah, Augustine H. "L'éthique de la différence en traduction : le cas de deux romans africains francophones et de leur restitution en anglais." Présence Francophone : Revue Internationale de Langue et de Littérature 70 (2008) : 113-35.

- Azodo, Ada Uzoamaka. "Thème Et Version : Teaching Translation with Mariama Bâ's Une Si Longue Lettre and So Long a Letter." Emerging Perspectives on Mariama Bâ : Postcolonialism, Feminism, and Postmodernism. Ed. Ada Uzoamaka Azodo. Trenton, NJ: Africa World, 2003. 277-301. 
- Ball, Nicole, and Leyla Ezdinli. Land of Many Colors and Nanna-ya. Lincoln, NE: U of Nebraska P, 1999.

- Batchelor, Kathryn. Decolonizing translation. Francophone African novels in English translation. Manchester: St. Jerome Publishing Ltd. 2009.

- Batchelor, Kathryn. "Third Spaces, Mimicry and Attention to Ambivalence." The Translator 14(1), 2008. 51-70.

- Bell, Sharon Masingale. "In the Shadow of the Father Tongue: On Translating the Masks in J.-S. Alexis." Between Languages and Cultures : Translation and Cross-Cultural Texts. Ed. Carol Maier. Pittsburgh, PA: U of Pittsburgh P, 1995. 51-74.

- Bell, Sharon Kay Masingale. "Instructing Revolution: Didacticism in the Short Stories of J. S. Alexis, with a Translation of His Romancéro aux étoiles." Dissertation Abstracts International 48.4 (1987): 933A.

- Blair, Dorothy S. "Translating Francophone Writing from West and North Africa." French Studies in Southern Africa 23(1994): 121-134.

- Bobb, Donald Frederick. "The Plays and Fiction of Cheik Aliou Ndao." Dissertation Abstracts International 43.7 (1983): 2346A.

- Briere, Eloise. "In Search of Cultural Equivalencies: Translations of Camara Laye's L'Enfant Noir." Translation Review 27 (1988): 34-9.

- Budig-Markin, Val, and Martha Manier. "Traduire Les Antilles En Anglais : Trahir Ou Fêter La Polyphonie ?" TTR 13.2 (2000) : 107-25.

- Chambers, Angela. "Nativism and Hybridity in Aimé Césaire's Poetic Vision." Challenges of Translation in French Literature. Oxford, England: Peter Lang, 2005. 207-219.

- Coates, Carrol F. "Problems of 'Translating' Bi-/Multi-Lingual Literary Texts: The Haitian French of Jacques Stephen Alexis." Translation Perspectives 11 (2000) : 275-85.

- Cordova, Sarah Davies. "Traduire la reine Pokou: Fidélité ou trahison?." Translation in French and Francophone Literature and Film. Amsterdam, Netherlands: Rodopi, 2009. 131-145..

- Cunningham, Catriona. "Beyond Translation into Chaos: Exploring Language Movement in the French Caribbean." Linguistica Antverpiensia 2. (2003): 61-73.

- Curtius, Anny Dominique. "The Great White Man of Lambaréné by Bassek Ba Kobhio: When Translating a Colonial Mentality Loses its Meaning." Translation in French and Francophone Literature and Film. Ed. Jeanne Garane. New York, NY: Rodopi, 2009. 115-130.

- De, Brito M. The Trickster's Tongue: An Anthology of Poetry in Translation from Africa and the African Diaspora with Introduction, Commentary and Bibliography. Leeds: Peepal Tree, 2006. 
- Deme, Dakha. "Réflexions sur la langue de Léopold Sédar Senghor." Etudes GermanoAfricaines: Revue Annuelle de Germanistique Africaine/Jahresschrift fur Afrikanische Germanistik/ Annual Review 4.(1986): 59-65.

- De Souza, Pascale. "Crossing the Bridge of Beyond: Translating the Mangroves of French Caribbean Identities." Emerging Perspectives on Maryse Condé: A Writer of Her Own.. Trenton, NJ: Africa World, 2006. 39-61.

- Diawara, Manthia. "The African Tale of Cinema." Discourse: Journal for Theoretical Studies in Media and Culture 11.2 (1989): 99-106.

- Dramé, Kandioura. "Senghor Translated by Melvin Dixon." Callaloo: A Journal of African American and African Arts and Letters 13.1 (1990): 28.

- Dumontet, Danielle. "Possibilités et limites des transferts culturels: Le Cas des romans La Reine Soleil levée de Gérard Etienne et Texaco de Patrick Chamoiseau." TTR 13.2 (2000): 149178.

- Echu, George. "Problématique De La Traduction De l'CEuvre De Ferdinand Oyono En Anglais : Etude d'Une Vie De Boy Et Le Vieux Nègre Et La Médaille." Ecce Homo, Ferdinand Léopold Oyono: Hommage à Un Classique Africain. Ed. Abdou Diouf. Paris, France: Karthala, 2007. 513-527.

- Edwards, Brent Hayes. "Aimé Césaire and the Syntax of Influence." Research in African Literatures 36.2 (2005): 1-18.

- Gibbs, James. "What Is Available?: New Literature, Canon Formation and Translation." West Africa. (1991): 1-7.

- Gyasi, Kwaku A. "Ahmadou Kourouma: Translation and Interpretation as Narrative Configurations in the African Text." The Creative Circle: Artist, Critic, and Translator in African Literature. Trenton, NJ: Africa World, 150-164. 2003.

- Hawkes, Sophie. "The Drama of Liberation, I: A Comparative Study of Aimé Césaire's Theater; II: A Translation of Césaire's And the Dogs Were Silent." Dissertation Abstracts International 48.7 (1988): 1762A.

- Hazaël-Massieux, Marie-Christine. "Récit, dialogue et traduction: A propos de quelques œuvres de la jeune littérature créole des Antilles." Langue et identité narrative dans les littératures de l'ailleurs: Antilles, Réunion, Québec. 125-142. Aix-en-Provence, France: Université de Provence, 2005.

- Hazaël-Massieux, M. "le théâtre créolophone dans les départements d'outre-mer. Traduction, adaptation contacts de langues." L'Annuaire théatral : revue québécoise d'études théâtrales 28 (2000): 21-34. 
- Ionescu, Mariana C. "L'Enonciation culturelle chez Panaï Istrati et Patrick Chamoiseau: Traduction ou trahison?." Voix Plurielles 5.2 (2008): 109-121.

- Jahn, Janheinz. "Senghor without Propeller: An English Translation That Does Not Get off the Ground." Black Orpheus: Journal of African and Afro-American Literature 19.(1966): 40-44.

- Jiyah, Jacob Haruna. "African Writers as Practising Translators: The Case of Ahmadou Kourouma". Translation Journal 6.4 (2002).

- Jones, Moya. "Chamoiseau and Matura: Translators and Translations." Palimpsestes 12. (2000): 61-70.

- Joseph, George. "A Translation of Pathé Diagne's 'Theses on Epistemology of the Real and the Neo-Pharaonic Problematic'." Research in African Literatures 24.3 (1993): 93-100.

- Kadish, Doris Y., and Françoise Massardier-Kenney. "Traduire Maryse Condé: Entretien avec Richard Philcox." French Review 69.5 (1996): 749-761.

- Karamcheti, Indira. "Aimé Césaire's Subjective Geographies: Translating Place and the Difference It Makes." Between Languages and Cultures: Translation and Cross-Cultural Texts.. Pittsburgh, PA: U of Pittsburgh P, 1995. 181-197.

- Lavoie, Judith. "Le Français créolisé comme option de traduction du vernaculaire noir américain." Présence Francophone: Revue Internationale de Langue et de Littérature 51. (1997): 116138.

- Linares, Immaculada. "L'Enjeu de traduire un poète." CEuvres \& Critiques: Revne Internationale d'Etude de la Réception Critique d'Etude des CEuvres Littéraires de Langue 19.2 (1994): 159-165.

- Lionnet, Françoise. "Creole Vernacular Theatre: Transcolonial Translations in Mauritius." MLN 118.4 (2003): 911-932.

- Malena, Anne. “Léonora parle-t-elle encore et à qui ?" TTR 10.1 (1997) : 197-217

- Malena, Anne. "Les Antilles en traduction/The Caribbean in Translation." TTR 13.2 (2000): $9-243$.

- Martin-Ogunsola, Dellita. "The Aesthetics of Culture Transfer in Langston Hughes's Translations of Works by Federico García Lorca, Nicolás Guillén, Jacques Roumain." Foreign Literature Studies/Wai Guo Wen Xue Yan Jiu 30.2 [130] (2008): 21-30.

- Mbangwana, Paul. "Cross Cultural Communication and Miscommunication through Connotation Usage in Translation : The Case of Two African Classics in Translation." Journal of Multilingual and Multicultural Development 11.4 (1990): 319-35. 
- Mehrez, Samia. "Translation and the Postcolonial Experience: The Francophone North African Text." Rethinking Translation: Discourse, Subjectivity, Ideology.. London: Routledge, 1992. 120-138.

- Michelman, Fredric. "From L'Enfant Noir to the Dark Child: The Drumbeat of Words Silenced." Toward Defining the African Aesthetic. Ed. Mildred Hill-Lubin. Washington, DC: Three Continents, 1982. 105-111.

- Mokwenye, Cyril. "La Traduction Anglaise De Gouverneurs De La Rosée De Jacques Roumain Par Langston Hughes Et Mercer Cook : Remarques Critiques." Babel : Revue Internationale de la Traduction/International Journal of Translation 39.4 (1993) : 225-32.

- N'Zengou-Tayo, Marie-José, and Elizabeth Wilson. "Translators on a Tight Rope: The Challenges of Translating Edwidge Danticat's Breath, Eyes, Memory and Patrick Chamoiseau's Texaco." TTR 13.2 (2000): 75-105.

- Ojo-Ade, Femi. "Problems of Translation in Black Literature: An Example of Aimé Cesaire's La Tragedie du Roi Christophe." Obsidian: Black Literature in Review 4.2 (1978): 5-18.

- Okawa, Rachelle. "Translating Maryse Condé's Célanire-cou-coupé: Dislocations of the Caribbean Self in Richard Philcox's Who Slashed Celanire's Throat? A Fantastical Tale." Translation in French and Francophone Literature and Film. Amsterdam, Netherlands: Rodopi, 2009. 161-177.

- Osei-Nyame, Jr K. "The Politics of 'translation' in African Postcolonial Literature: Olaudah Equiano, Ayi Kwei Armah, Toni Morrison, Ama Ata Aidoo, Tayeb Salih and Leila Aboulela." Journal of African Cultural Studies. 21.1 (2009): 91-103.

- Patterson, Anita. "Forgotten Manuscripts: 'And Bid Him Translate: Langston Hughes's Translations of Poetry from French,' by Alfred Guillaume." African American Review 41.3 (2007): 407-410.

- Pfaff, Françoise. "Translating Maryse Condé's Caribbeanness into English." CLA Journal 53.2 (2009): 145-161.

- Philcox, Richard. "Translating Maryse Condé: A Personal Itinerary." Emerging Perspectives on Maryse Condé: A Writer of Her Own.. Trenton, NJ: Africa World. 2006. 33-38.

- Schaefer, Judith. "En Attendant Le Vote Des Bêtes Sauvages, by Ahmadou Kourouma: A Comparison of Two English Translations." Translation Review 67 (2004): 58-71.

- Schild, Ulla. "'O lumière amicale': Descente dans les archives de Janheinz Jahn." Oeuvres \& Critiques: Revue Internationale d'Etude de la Réception Critique d'Etude des Oeuvres Littéraires de Langue 19.2 (1994): 151-158.

- Shread, Carolyn. "La Traduction Métra Morphique : Entendre Le Kreyòl Dans La Traduction Anglaise Des Rapaces De Marie Vieux-Chauvet." Palimpsestes 22 (2009): 225. 
- Stahl, Aletha. "Does Hortense Have a Hoo-Hoo? Gender, Consensus and the Translation of Gisèle Pineau's L'espérance macadam ” TTR. 13.2(2000): 127-148

- Taylor, Lucien. "The Same Difference." Transition: An International Review 63.(1994): 98-111.

- Toler, Michael. "The ethics of cultural representation: the Maghribi novel in English translation". Journal of North African Studies 6.3(2001): 48 -69.

- Toman, Cheryl. "Werewere Liking as Translator and Translated." Translation in French and Francophone Literature and Film. Ed. Jeanne Garane. New York, NY : Rodopi, 2009. 101-114.

- Van Den Abbeele, Georges. "The French Language in the Face of Creolization." French Civilization and Its Discontents: Nationalism, Colonialism, Race. Lanham, MD: Lexington, 2003. 105-113.

- Veldwachter, Nadège. "Simone Schwarz-Bart, Maryse Condé, and Raphaël Confiant in English Translation: Texts and Margins." Research in African Literatures 40.2 (2009): 228-239.

- Warner, Tobias. "Bodies and Tongues: Alternative Modes of Translation in Francophone African Literature." Translation, Biopolitics, Colonial Difference. Ed. Jon Solomon. Hong Kong : Hong Kong UP, 2006. 295-325.

- Williams, John. "Beyond Languages and Color." Discourse: Journal for Theoretical Studies in Media and Culture 11.2 (1989): 109-113.

- Wilson, Elizabeth A. "Translating Caribbean Landscape." Palimpsestes 12.(2000): 15-29.

- Woodham, Kathryn. "Translating Texts that Play: Werewere Liking's 'Elle sera de jaspe et de corail' and its Translation into English”. Ed. Irène Assiba D'Almeida \& Conteh-Morgan John. "The Original Explosion That Created Worlds". Essays on Werewere Liking's Art and Writings. New York: Rodopi, 2010.

- Woodham, Kathryn. "Linguistic Decolonisaton and Recolonisation? Fluent Translation Strategies in the Context of Francophone African Literature.” Ed. R.J. Granqvis. Writing Back in/ and Translation. Oxford: Peter Lang, 2006. 119-128.

- Woodham, Kathryn. "From Congolese Fisherman to British Butler: Francophone African Voices in English Translation.” Eds. M. Armstrong \& F.M., Federici. Translating Voices, Translating Regions. Rome: Aracne, 2006. 401-417.

- Woodham, Kathryn. "Cultural Insularity and Reactive Decision-Making: The Canon of SubSaharan Francophone African Novels in English Translation." The Global Literary Field. Newcastle upon Tyne, England: Cambridge Scholars, 2006. 182-199. 
- Woodham, Kathryn. «Analyse de textes san (parler de Toma): aperçu des traits caractéristiques du genre narratif d'une langue mandé du Burkina Faso. » Cologne: Koeppe, 2003.

- Woodham, Kathryn. "Should Domestication vs Foreignisation be the Sixth Supermeme?." Norwich Papers, 10, 2002. 136-147. 